\title{
MICROBIAL PROTEIN SYNTHESIS IN YOUNG STEERS FED WITH GRASS SILAGE AND EXTRUDED CORN
}

\author{
Claudia Barchiesi-Ferrari ${ }^{1,2 *}$, and René Anrique ${ }^{2}$
}

\begin{abstract}
Microbial protein synthesis is essential to meet protein requirements in ruminants. The aim of this investigation was to evaluate the effect of incorporating extruded corn (Zea mays L.) into the ration of young steers fed with grass silage on microbial protein synthesis (MPS). Twenty young steers in metabolic cages were used for supplying food. The treatments consisted of combinations of extruded corn (EC) and ground corn (GC) EC-10 (10\% EC-30\% GC); EC-25 (25\% EC-15\% GC) and EC-40 (40\% EC-0\% GC). These foods constituted $40 \%$ of the ration (DM-based) and the remaining $60 \%$ was grass silage. The MPS was calculated through the excretion of purine derivatives (PD) in the urine, using total collection of urine. The inclusion of a higher percentage of extruded corn (EC-40) increased the PD excretion $\left(51.85 \mathrm{mmol} \mathrm{d}^{-1}, \mathrm{P}<0.05\right)$. The values of PD excretion ranged between 663 and $1078 \mu \mathrm{mol} \mathrm{BW}^{-0.75} \mathrm{~d}^{-1}$. The microbial protein absorption and flow of duodenal $\mathrm{N}$ also increased with a higher portion of extruded corn $(\mathrm{EC}-40, \mathrm{P}<0.05)$. The differences between treatments can be explained by the effect of corn extruding. This allows more energy available for ruminal bacteria and improved synchrony between energy and protein.
\end{abstract}

Key words: Purine derivatives, extrusion, allantoin, microbial protein synthesis, Zea mays.

$\mathrm{M}$ icrobial protein synthesis (MPS) in the rumen is essential to meet protein requirements in ruminants. It has been reported that more than half of protein requirements in high-production dairy cows is covered by the flow of microbial protein (MP) towards the duodenum (Tas and Susenbeth, 2007). The conversion of degradable protein into MP in the rumen requires the contribution of energy for ruminal microorganisms (Beever and Cottrill, 1994; Firkins et al., 2007). Microbial protein production is generally considered proportional to the energy available for fermentation in the absence of acidosis; however, the efficiency of microbial protein synthesis (EMPS) is affected by other factors, including those that emphasize feeding level and ruminal synchrony (Dewhurst et al., 2000; Shingfield, 2000). The use of diets with a high nonstructural carbohydrate content increases passage rate, the supply of metabolizable energy and intestinal digestible protein, and EMPS (Firkins et al., 2006). Nevertheless, in order to maintain a suitable ruminal $\mathrm{pH}$, a structural carbohydrate intake is also needed (Allen, 1997).

Different methods have been used to calculate MPS. Some of these are based on measurements of digesta flow, which requires fistulated animals and microbial

${ }^{1}$ Universidad de La Frontera, Facultad de Ciencias Agropecuarias y Forestales, Avda. Francisco Salazar 01145, Casilla 54-D, Temuco, Chile. "Corresponding author (cbarchi@ufro.cl).

${ }^{2}$ Universidad Austral de Chile, Facultad de Ciencias Agrarias, Casilla 567, Valdivia, Chile.

Received: 2 April 2012.

Accepted: 25 June 2012. markers, thereby rendering these methods questionable from the point of the animal's well-being (Shingfield, 2000; González-Ronquillo et al., 2004). There are also discrepancies between estimations of microbial $\mathrm{N}$ flow towards the duodenum with the use of different markers (Shingfield, 2000). The estimation of MPS from purine derivatives (PD) in the urinary excretion is a simple and non-invasive method that needs only the quantitative collection of urine. Purine derivatives come from the degradation of endogenous (released during the catabolism of nucleic acids in the tissue) and exogenous (from the intestine) purines (Verbic et al., 1990). As quantitative relationship exists between intestinal absorption and urinary excretion of $\mathrm{PD}$, they may be used to calculate the intestinal flow of MP (Chen et al., 1992). In addition, quantifying PD makes it possible to evaluate the EMPS via the balance between energy and protein in the rumen (Chen et al., 1990; Martín-Orúe et al., 2000).

Corn (Zea mays L.) is used as an energy supplement for fattening and milk production due to its ability to increase production of propionate at rumen level (Russell, 1998). Nevertheless, its vitreous endosperm is composed of a protein starch matrix, which makes it more resistant than other cereals to enzymatic hydrolysis by rumen bacteria (Rooney and Pflugfelder, 1986). In addition, ruminal digestibility of starch decreases when amylase content increases (Svihus et al., 2005), which in corn is generally high and can reach $650-700 \mathrm{~g} \mathrm{~kg}^{-1}$ (Parker and Ring, 2001). This poses a limitation for the use of corn in grass silage-based diets owing to the difficulty 
in obtaining a suitable synchronization between the $\mathrm{N}$ quickly available from silage and the energy insufficiently supplied by the corn. Gelatinization of starch caused by extrusion, however, facilitates its degradation, increasing the energy available and improving the synchronization between energy and protein in the rumen (Svihus et al., 2005).

According to the evidence in the literature, including corn in grass silage-based diets might increase the MPS in young steers. The aim of the present study was to evaluate the effect of the level of inclusion of extruded corn on microbial protein synthesis in young steers fed with a grass silage-based diet.

\section{MATERIALS AND METHODS}

\section{Animals and feed}

The trial was conducted at the Vista Alegre Experimental Station located $6 \mathrm{~km}$ north of the city of Valdivia (39 $47^{\circ}$ S; $\left.73^{\circ} 12^{\prime} \mathrm{W}\right)$, Chile, between September and November 2004. Twenty young Friesian steers were used, separated in two weight categories: light (155 kg average BW) and heavy (185 kg average BW), placed in metabolic cages. The animals were divided into two groups to properly adjust the consumption, in the absence of animals of similar weight.

Three combinations of extruded corn (EC) and ground corn (GC) were used, respectively: 10/30 (EC-10), 25/15 (EC-25) and 40/0 (EC-40). Corn represented $40 \%$ of the diet (DM-based) and the remaining 60\% was completed with direct cut grass silage (DM-based), prepared from a mix of Lolium perenne-Avena sativa, to which sugar beet pulp was added as an absorbent at the rate of 30 $\mathrm{kg} \mathrm{t}^{-1}$ fresh forage. Corn, previously milled to $2.5 \mathrm{~mm}$, was extruded at $90{ }^{\circ} \mathrm{C}$ with a pressure of 15 to $20 \mathrm{~atm}$, followed by cooling and drying at room temperature with a final humidity of $12-14 \%$. To prepare the diets, the extruded corn was ground using a $2.5 \mathrm{~cm}$ sieve. In addition a mineral mixture was provided. The nutritional composition of the feed is presented in Table 1.

The diets were evaluated through a digestibility trial with the total collection of feces and urine. Animals had a 15-d adaptation period before samples were collected. Intake was adjusted to $80 \%$ of requirements to ensure

Table 1. Nutritional composition of extruded corn, ground corn and grass silage used in diets (\%, Mcal kg $\left.{ }^{-1} \mathrm{DM}\right)$.

\begin{tabular}{lrrr}
\hline & $\begin{array}{c}\text { Extruded } \\
\text { corn }\end{array}$ & $\begin{array}{c}\text { Ground } \\
\text { corn }\end{array}$ & $\begin{array}{c}\text { Grass } \\
\text { silage }^{1}\end{array}$ \\
\hline Dry matter, \% & 84.45 & 84.23 & 15.80 \\
Ash, \% & 1.34 & 1.42 & 7.09 \\
Crude protein, \% & 7.83 & 8.17 & 14.80 \\
Neutral detergent fiber, \% & 8.43 & 11.98 & 58.55 \\
Acid detergent fiber, \% & 2.20 & 2.69 & 38.74 \\
Metabolizable energy ${ }^{2}$, Mcal kg $^{-1} \mathrm{DM}$ & 3.47 & 3.47 & 2.56 \\
pH & & & 4.15 \\
$\mathrm{~N}-\mathrm{NH}_{3}, \% \mathrm{~N}$ & & & 11.59 \\
\hline${ }^{1}$ Oven dried at $60^{\circ} \mathrm{C}$ and at $105{ }^{\circ} \mathrm{C}$. & & \\
${ }^{2}$ Estimated by D value. & & &
\end{tabular}

total consumption. The animals were fed thrice a day, at 09:00, 13:00, and 17:00 h, and had fresh water available at all times. The amounts of feed offered per treatment are shown in Table 2 (Alvarado et al., 2009).

\section{Sample collection}

Daily samples representative of each food were collected to prepare composite samples at the end of the trial. The silage samples were frozen at $-20{ }^{\circ} \mathrm{C}$ until laboratory analysis.

Urine was collected daily for $6 \mathrm{~d}$ in plastic containers placed under the cages, completely covered by a double layer of cotton fabric to avoid fecal contamination. The urine flowed directly into the containers through a metal grid in the floor. Urine samples were taken once a day at 08:00 h. In order to maintain urine $\mathrm{pH}$ below 3.0 (Fujihara et al., 1991) and to avoid PD losses and to prevent microbial activity $34 \mathrm{~mL}$ of $\mathrm{H}_{2} \mathrm{SO}_{4} 1 \mathrm{M} 100 \mathrm{~mL}^{-1}$ of urine were added (Fujihara et al., 1991). The pH was checked with Panpeha $\mathrm{pH}$ indicator strips (Whatman) and $\mathrm{H}_{2} \mathrm{SO}_{4}$ in case $\mathrm{pH}$ raised above 3.0 an extra amount of $\mathrm{H}_{2} \mathrm{SO}_{4}$ solution was added. To keep the uric acid from precipitating, each sample was diluted at a rate of 20 $\mathrm{mL}$ of urine and $80 \mathrm{~mL}$ of distilled water. The individual urine daily samples were stored at $20{ }^{\circ} \mathrm{C}$ in duplicates. In addition, individual fecal production was measured daily; after homogenization, $3 \%$ of the daily excretion was sampled and stored at $-20{ }^{\circ} \mathrm{C}$.

\section{Analytical procedures}

In feed and feces, dry matter (DM) (AOAC, 1996, method 930.15), crude protein (CP) by Micro Kjeldhal (AOAC, 1996, method 984.13), total ash (Ash) (AOAC, 1996, method 942.05), acid detergent fiber (ADF) (AOAC, 1996, method 973.18), neutral detergent fiber (NDF) (Van Soest et al., 1991), and metabolizable energy (ME) were determined. Metabolizable energy was estimated by regression from $\mathrm{D}$ value (digestible organic matter in the DM) determined in vitro (Goering and Van Soest, 1972). Fecal DM was determined using lyophilization.

Microbial protein synthesis was estimated from the urinary excretion of the purine derivatives allantoin and uric acid (Chen and Gomes, 1992). The total daily volume of urine per animal from three days consecutive was used.

Table 2. Ingredients of the experimental rations for each treatment (DM basis).

\begin{tabular}{lcccc}
\hline Diet & $\begin{array}{c}\text { Animal } \\
\text { category }\end{array}$ & $\begin{array}{c}\text { Extruded } \\
\text { corn }\end{array}$ & $\begin{array}{c}\text { Ground } \\
\text { corn }\end{array}$ & $\begin{array}{c}\text { Grass } \\
\text { silage }\end{array}$ \\
\hline \multirow{2}{*}{ EC-10 } & H & 0.45 & 1.34 & 14 \\
& $\mathrm{~L}$ & 0.38 & 1.12 & 12 \\
EC-25 & $\mathrm{H}$ & 1.12 & 0.67 & 14 \\
& $\mathrm{~L}$ & 0.94 & 0.56 & 12 \\
EC-40 & $\mathrm{H}$ & 1.79 & - & 14 \\
& $\mathrm{~L}$ & 1.50 & - & 12 \\
\hline
\end{tabular}

EC-10: $10 \%$ extruded corn - 30\% ground corn; EC-25: $25 \%$ extruded corn - 15\% ground corn; EC-40: $40 \%$ extruded corn - 0\% ground corn; $\mathrm{H}$ : heavy animals $(\mathrm{BW}=185 \mathrm{~kg})$; $\mathrm{L}$ : light animals $(\mathrm{BW}=155 \mathrm{~kg})$. 
Allantoin concentration was determined colorimetrically using the method described by Chen and Gomes (1992). Uric acid was determined colorimetrically using a diagnostic uric acid reagent ( $\mathrm{N}^{\circ} 685$; Sigma, USA). The total urinary excretion of PD was calculated from the sum of the values of allantoin and uric acid, expressed in mmol $\mathrm{d}^{-1}$ (Chen and Gomes, 1992).

\section{Calculations}

Total tract digestibility of the organic matter (OM) was calculated relating daily organic matter intake (OMI) and daily OM excretion. Digestible OM intake (DOMI) was calculated from OM digestibility and daily OM intake. Organic matter truly digested in the rumen (OMTDR; $\mathrm{kg}$ $\left.\mathrm{d}^{-1}\right)$ was calculated from the relationship OMTDR $=0.55$ $\times$ OMI (Stern et al., 1994; Südekum et al., 2006). The OM apparently digested in the rumen (OMADR, $\mathrm{kg} \mathrm{d}^{-1}$ ) was determined by the relationship: OMADR $=0.60 \times$ DOMI (Schröder et al., 1997; Südekum et al., 2006).

Total PD excretion was the result of the sum of the urinary excretions of allantoin and uric acid. Absorbed purines of microbial origin $\left(\mathrm{X}, \mathrm{mmol} \mathrm{d}^{-1}\right)$ were calculated according to the equation of Verbic et al. (1990):

$$
\mathrm{Y}=0.85 \mathrm{X}+\left(0.385 \times \mathrm{BW}^{0.75}\right)
$$

where, $\mathrm{Y}$ is the total urinary $\mathrm{PD}$ excretion $(\mathrm{mmol}$ $\left.\mathrm{d}^{-1}\right) ; 0.385 \mathrm{BW}^{0.75}$ is the net contribution of PD to total excretion after correction for the utilization of microbial purines by the animal; 0.85 is the recovery factor as PD of the purines absorbed in the urine; and $\mathrm{X}$ is the intestinal purine absorption $\left(\mathrm{mmol} \mathrm{d}^{-1}\right)$.

Duodenal flow of microbial N (Chen and Gomes, 1992) was obtained from the following equation:

Microbial N $\left(\mathrm{g} \mathrm{N} \mathrm{d}^{-1}\right)=\mathrm{X}\left(\mathrm{mmol} \mathrm{d}^{-1}\right) \times 70 / 0.116 \times 0.83$

$$
\times 1000
$$

where $\mathrm{X}$ is the amount of microbial purines absorbed $\left(\mathrm{mmol} \mathrm{d}^{-1}\right) ; 70 \mathrm{mg} \mathrm{N} \mathrm{mmol}^{-1}$ is the $\mathrm{N}$ content in the purines; 0.116 is the relation between purine $\mathrm{N} /$ total $\mathrm{N}$ in the mixed microbial biomass (11.6:100) and 0.83 is the digestibility of the microbial purines.

EMPS $\left(\mathrm{g} \mathrm{N} \mathrm{kg}^{-1}\right)$ was expressed in terms of N/DOMI; and N/OMADR.

\section{Statistical analysis}

The data were analyzed by means of the GLM procedure, using a one-way ANOVA. The statistical model was: $\mathrm{Y}_{\mathrm{ij}}=$ $\mu+\mathrm{M}_{\mathrm{i}}+\mathrm{e}_{\mathrm{ij}}$; where $\mathrm{Y}_{\mathrm{ij}}$ represents the response variable; $\mu$ the total average; $\mathrm{M}_{\mathrm{i}}$ the effect of the level of extruded corn on the diet $(10 \%, 25 \%, 40 \%)$, and $\mathrm{e}_{\mathrm{ij}}$ the residual error. The averages were compared using the Tukey test, with $\mathrm{P}$ $<0.05$. The statistical analyses were performed using the statistical program JMP, version 8 (SAS Institute, 2009).

\section{RESULTS AND DISCUSSION}

\section{Nutritional composition of the feed}

The nutritional composition of feed is shown in Table
1. When comparing the composition of GC with EC, slightly higher values of $\mathrm{CP}$ (8.17 vs. $7.83 \%), \mathrm{NDF}(11.98$ vs. $8.43 \%)$ and $\mathrm{ADF}$ (2.69 vs. $2.20 \%$ ) respectively were observed, as well as a similar ME content. The CP content of the silage was $14.8 \%$ and the $\mathrm{N}^{-\mathrm{NH}_{3}}$ was $11.59 \%$ of the total $\mathrm{N}$.

The grass silage presented a higher CP content (14.8\%) than the average for direct cut lolium-oat silages in southern Chile (12.4\% CP, Anrique et al., 2008), whereas ME values (2.56 vs. $2.50 \mathrm{Mcal} \mathrm{kg}^{-1} \mathrm{DM}$ ) and $\mathrm{pH}$ values ( 4.15 vs. 4.10$)$ were similar to the average values. The low DM content in the silage is explained by the use of an absorbent additive that represented $14 \%$ of the ensiled DM. The $\mathrm{N}^{-\mathrm{NH}_{3}}$ content $(11.59 \%$ total $\mathrm{N})$ was greater than expected, which might be explained by the high moisture content that extends the fermentation process and favors heterolactic fermentation and microbial proteolysis (Harrison et al., 1994). It must be considered that once the forage is harvested, proteolysis begins due to the action of proteases of plants and microorganisms (Givens and Rulquin, 2004). The greatest consequence of proteolysis is that the resulting $\mathrm{N}$ compounds are highly soluble, which negatively affects their use by ruminal microorganisms (Givens and Rulquin, 2004).

The reduction in the NDF content in the corn as a result of extrusion has also been observed in lupins, mixtures of pea with extruded rapeseed cakes, extruded cereals, and rapeseed cakes (Cros et al., 1991; Chapoutot and Sauvant, 1997; Solanas et al., 2008; Barchiesi and Anrique, 2011). This reduction may be due to a partial depolymerization of polysaccharides of the cell wall, make them more soluble in acid and alkaline solutions used in fiber analysis (Solanas et al., 2005).

\section{Urinary PD excretion and flow of microbial $\mathbf{N}$}

The daily excretion of $\mathrm{PD}$, allantoin and uric acid, the absorbed PD of microbial origin and the flow of microbial $\mathrm{N}$ are presented in Table 3 . The total urinary PD excretion ranged between 31.7 and $51.9 \mathrm{mmol} \mathrm{d}^{-1}$ and 663 and 1078 $\mu \mathrm{mol} \mathrm{BW}^{-0.75}$ per day, being significantly higher in the treatment that included the highest proportion of extruded corn $(\mathrm{EC}-40, \mathrm{P}<0.05)$. In the EC-40 treatment, total

Table 3. Urinary excretion of purine derivatives (PD), allantoin, and uric acid components, $\mathrm{PD} / \mathrm{BW}^{0.75}$, absorbed microbial purines and flow of

\begin{tabular}{|c|c|c|c|c|c|}
\hline & EC-10 & EC-25 & EC-40 & SEM & $\mathrm{P}$ \\
\hline $\begin{array}{l}\text { PD excretion, } \text { mmol d}^{-1} \text { : } \\
\text { total }\end{array}$ & $31.66 \mathrm{a}$ & $34.30 \mathrm{a}$ & $51.85 \mathrm{~b}$ & 5.69 & * \\
\hline allantoin & $31.48 \mathrm{a}$ & $34.15 \mathrm{a}$ & $51.36 \mathrm{~b}$ & 6.06 & * \\
\hline uric acid & $0.18 \mathrm{a}$ & $0.15 \mathrm{a}$ & $0.49 \mathrm{~b}$ & 0.11 & * \\
\hline $\begin{array}{l}\text { PD BW }{ }^{-0.75} \text { excretion, } \\
\mu \mathrm{mol} \mathrm{BW}^{-0.75}\end{array}$ & $663.17 \mathrm{a}$ & $706.11 \mathrm{a}$ & $1078.32 b$ & 106.39 & * \\
\hline $\begin{array}{l}\text { Absorbed microbial purines, } \\
\mathrm{mmol} \mathrm{d}^{-1}\end{array}$ & $16.19 \mathrm{a}$ & $18.96 \mathrm{a}$ & $39.38 b$ & 6.57 & * \\
\hline Microbial $\mathrm{N}$ flow, $\mathrm{g} \mathrm{N} \mathrm{d}^{-1}$ & $11.77 \mathrm{a}$ & $13.78 \mathrm{a}$ & $28.63 b$ & 4.77 & * \\
\hline
\end{tabular}
microbial $\mathbf{N}$ per treatment.

EC-10: $10 \%$ extruded corn -30\% ground corn; EC-25: $25 \%$ extruded corn -15\% ground corn; EC-40: $40 \%$ extruded corn $-0 \%$ ground corn. Different letter within rows indicate significant differences according to Tukey test $(\mathrm{P}<0.05)$.

SEM: standard error of the mean. 
PD excretion was $38.71 \%$ and $33.51 \%$ greater than in the EC-10 and EC-25 treatments, respectively. Allantoin excretion in all the treatments represented more than $99 \%$ of the total PD excretion, with the minimum being the uric acid excretion. The absorption of purines of microbial origin increased proportionally to the intake of EC and ranged between 16.19 and $39.38 \mathrm{mmol} \mathrm{d}^{-1}$. The flow of microbial $\mathrm{N}$ to the duodenum ranged between 11.77 and $28.63 \mathrm{~g} \mathrm{~N} \mathrm{~d}^{-1}$ and was greater in the EC-40 treatment $(\mathrm{P}<$ $0.05)$ with respect to the lowest levels of inclusion of EC.

The PD excreted in the urine arises from intestinal absorption of microbial purines and purines from animal tissues, although the latter make only a slight contribution to total PD excretion (Chen et al., 1992). PD excretions found in this study agree with values between 638 and $1304 \mu \mathrm{mol} \mathrm{BW}{ }^{-0.75} \mathrm{~d}^{-1}$ reported for heifers by Martín-Orúe et al. (2000). On the other hand, they are greater than the values of 428 and $514 \mu \mathrm{mol} \mathrm{BW} \mathrm{BW}^{-0.75} \mathrm{~d}^{-1}$ found for young steers and dairy cows, respectively, reported by Verbic et al. (1990) and Chen et al. (1990), using intragastric infusion of casein. Differences were observed in the PD excretion between studies may be explained in part by the use of different animal species or categories, and by differences in the methodologies used.

Total PD excretion $\left(\mathrm{mmol} \mathrm{d}^{-1}\right)$ of this study (between 31.66 and $51.85 \mathrm{mmol} \mathrm{d}^{-1}$ ) is lower than the values reported for urinary excretion by Martín-Orúe et al. (2000) (53.7 and $104.4 \mathrm{mmol} \mathrm{d}^{-1}$ ). The PD excretion values in the EC-10 and EC-25 treatments are also lower than those presented by Verbic et al. (1990) (51.5 and $45.7 \mathrm{mmol} \mathrm{d}^{-1}$, in two experiments). Südekum et al. (2006) suggest that at low intake levels, the energy and the nutrients are ingested almost exclusively for the purpose of maintaining ruminal microorganisms; once intake exceeds these maintenance requirements, an increasing proportion of the nutrients can be used for the growth of ruminal microorganisms. According to Fujihara and Shem (2011) the movement of nucleic acids from tissue is influenced by the animal's metabolic activity, and when the MP contribution is calculated using the urinary PD excretion in ruminants fed at sub-maintenance levels, this must be considered a loss of endogenous PD. In this investigation the DM intake was fixed at $80 \%$ of the ad libitum intake, which could have limited microbial growth to a certain extent.

Some authors (Chen et al., 1990; Chen and Gomes, 1992; Shingfield, 2000; González-Ronquillo et al., 2004) report that allantoin represents between 82 and $90 \%$ of the total urinary PD excretion. However, in this investigation the allantoin level was over $99 \%$ of total, PD with very low uric acid content (Table 3 ). These results agree with the low uric acid contents obtained in dairy cows by GonzalezRonquillo et al. (2003). In this regard, Verbic et al. (1990) suggest that bovine tissue may have uricase activity, which might explain the low values of uric acid obtained.

The MP calculated based on the PD excretion corresponds more to the amount of microbial biomass that reaches the duodenum (or duodenal flow of microbial $\mathrm{N})$ than to the growth of microorganisms in the rumen, representing the supply of microbial $\mathrm{N}$ to the host animal (Chen et al., 1992). In this work, it was observed that the use of EC as the only amylaceous concentrate produced a significant increase in the duodenal flow of microbial $\mathrm{N}$. Although GC, with a relatively high fraction of resistant starch is commonly used as fermentable energy source, starch does not facilitate enzyme activity, backed by results showing that different corn processing procedures, e.g. grinding, pelletizing, extrusion and expansion, increase rumen degradability of starch (Offner et al., 2003; Svihus et al., 2005). A greater availability of energy from starch should be reflected in a greater MPS, which in this study was only evident when EC was used exclusively. According to Beever and Cottrill (1994), when the contribution of $\mathrm{N}$ is not limiting for microorganisms, the MP production is considered to be energy-dependent. In silage-based diets, the end products of fermentation can contribute between 15\% (Beever and Cottrill, 1994) and $26 \%$ (Harrison et al., 1994) of the ME consumed, with the rest of the ME contribution depending on OM intake. Although the VFA can be absorbed and supply energy to ruminants, they cannot be used as a source of energy by the ruminal microorganisms (Harrison et al., 1994). In addition, carbohydrates with different fermentation and passage rates together with the effect on rumen $\mathrm{pH}$ can affect the maintenance requirements of microorganisms (National Research Council, 2000; Karsli and Russell, 2001). In this research, DM and energy intake did not differ among treatments, and therefore the greater PD excretion in EC-40 was a result of using EC.

\section{Efficiency of microbial protein synthesis}

The values of total intake of digestible OM (DOM) and digested OM in the rumen, both apparent (OMADR) and true (OMTDR), in addition to the EMPS $\left(\mathrm{g} \mathrm{N} \mathrm{kg}^{-1}\right)$ for the same parameters are shown in Table 4 . There were no differences between the treatments in intake of MOD, OMADR, and OMTDR (P > 0.05); however, the EMPS increased with the increasing inclusion of $\mathrm{EC}$, and the increase was two times greater in EC-40 compared to EC$10(\mathrm{P}<0.05)$, independently of the form of the expression of intake (DOM, OMADR, or OMTDR). EMPS ranged between 7.02 and $16.50 \mathrm{~g} \mathrm{~N} \mathrm{~kg}^{-1}$ of OMADR. Several authors have reported that DOM intake can be a good estimator of the EMPS when there is adequate $\mathrm{N}$ intake (AFRC, 1992; Chen et al., 1992). The EMPS values obtained in the EC-10 and EC-25 treatments (Table 4) were lower than the range of 12.0 and $28.3 \mathrm{~g} \mathrm{~N} \mathrm{~kg}^{-1}$ OMTDR reported for ewes by Chen et al. (1992) and the range of 25 to $27 \mathrm{~g} \mathrm{~N}$ OMADR found for steers by Südekum et al. (2006). Furthermore, the results from Orellana et al. (1998) obtained with dairy cows match those obtained in our study for the highest intake of EC (between 13 and 17 $\mathrm{g} \mathrm{N} \mathrm{kg}^{-1}$ DOMR), with the highest EMPS corresponding 
Table 4. Intake and digestibility of organic matter, purine derivatives excretion of digestible organic matter intake and efficiency of microbial protein synthesis in young steers.

\begin{tabular}{|c|c|c|c|c|c|}
\hline & \multicolumn{3}{|c|}{ Treatments } & \multirow[b]{2}{*}{ SEM } & \multirow[b]{2}{*}{$\mathrm{P}$} \\
\hline & EC-10 & EC-25 & EC-40 & & \\
\hline \multicolumn{6}{|l|}{ Intake, $\mathrm{kg} \mathrm{d}^{-1}$ : } \\
\hline DOMI & 2.95 & 2.96 & 2.93 & 0.106 & ns \\
\hline OMADR & 1.77 & 1.78 & 1.76 & 0.063 & ns \\
\hline OMTDR & 2.16 & 2.16 & 2.09 & 0.069 & ns \\
\hline Digestibility, $\%^{1}$ & 75.30 & 75.12 & 77.13 & 0.88 & ns \\
\hline \multicolumn{6}{|l|}{ EMPS, g N kg-1: } \\
\hline N/DOMI & $4.21 \mathrm{a}$ & $4.66 \mathrm{a}$ & $9.90 \mathrm{~b}$ & 1.57 & * \\
\hline N/OMADR & $7.02 \mathrm{a}$ & $7.77 \mathrm{a}$ & $16.50 \mathrm{~b}$ & 2.62 & * \\
\hline N/OMTDR & $5.63 \mathrm{a}$ & $6.33 \mathrm{a}$ & $13.83 \mathrm{~b}$ & 2.13 & * \\
\hline
\end{tabular}

DOMI: Digestible organic matter intake; OMADR: organic matter apparently degraded in the rumen; OMTDR: organic matter truly degraded in the rumen; EMPS: efficiency of microbial protein synthesis; EC-10: $10 \%$ extruded corn -30\% ground corn; EC-25: $25 \%$ extruded corn $-15 \%$ ground corn; EC- 40 : $40 \%$ extruded corn $-0 \%$ ground corn; SEM: standard error of the mean; ns: non significant.

'Organic matter apparently digested in the whole tract.

Different letter within rows indicate significant differences according to Tukey test $(\mathrm{P}<$ $0.05)$

to the highest concentrate levels. In diets based on highquality grass, the EMPS can reach high values (30-45 g microbial $\mathrm{N} \mathrm{kg}^{-1}$ OMADR (Givens and Rulquin, 2004), however, with a grass silage based-diet, the EMPS drops considerably, to levels of $23 \mathrm{~g}$ microbial $\mathrm{N} \mathrm{kg}^{-1}$ OMADR (ARC, 1984), which are slightly higher than the highest value obtained in this work. The lower EMPS with silagebased diets could be explained by a low availability of energy for the microorganisms in the rumen.

In this investigation, silages would not have supplied the energy necessary for a good balance between the soluble $\mathrm{N}$ and rapid degradability, and only the incorporation of extruded corn (EC-40) in the diet allowed for a greater EMPS, which would indicate a better balance between energy and protein in the rumen.

\section{CONCLUSIONS}

When extruded corn was completely substituted for ground corn in the diet, a significant increase in the excretion of purine derivatives and the duodenal flow of microbial $\mathrm{N}$ was observed and the efficiency of microbial protein synthesis doubled. With partial substitution levels of extruded corn for ground corn, there were no differences in the excretion parameters of purine derivatives, duodenal flow of $\mathrm{N}$ or the efficiency of microbial protein synthesis, suggesting that extruded corn in the highest dose increased the availability of energy, thus improving the productivity of rumen fermentation.

\section{ACKNOWLEDGEMENTS}

The authors wish to thank Soledad Navarrete for collecting the samples for the digestibility trial, and to Dr. Hernán Palma for his help with the purine analyses. C. Barchiesi was supported with a scholarship from the Higher Education MECE Program of the Chilean Ministry of Education to pursue doctoral studies in the Faculty of Agrarian Sciences, Universidad Austral de Chile.
Síntesis de proteína microbiana en novillos jóvenes alimentados con ensilaje de praderas y maíz extruido. La síntesis de proteína microbiana es fundamental para satisfacer los requerimientos proteicos en rumiantes. El objetivo de esta investigación fue evaluar el efecto de incluir maíz (Zea mays L.) extruido en la ración de novillos alimentados con ensilaje de pradera, sobre la síntesis de proteína microbiana (MPS). Se emplearon 20 novillos jóvenes ubicados en jaulas metabólicas para suministro de los alimentos. Los tratamientos consistieron en combinaciones de maíz extruido (EC) y maíz molido (GC) EC-10 (10\% EC-30\% GC); EC-25 (25\% EC$15 \%$ GC) y EC-40 (40\% EC-0\% GC). Estos alimentos constituyeron el $40 \%$ de la ración (base MS) y el restante $60 \%$ fue ensilaje de pradera. Se estimó la MPS a través de la excreción de derivados de purinas (PD) en la orina, empleando colección total de orina. La inclusión de un mayor porcentaje de EC (EC-40) incrementó la excreción de PD $\left(51.85 \mathrm{mmol} \mathrm{d}^{-1}, \mathrm{P}<0,05\right)$. Los valores de excreción de PD fluctuaron entre 663 y $1078 \mu \mathrm{mol} \mathrm{BW}^{-0.75} \mathrm{~d}^{-1}$. La absorción de proteína microbiana y el flujo de $\mathrm{N}$ duodenal también se incrementaron por una mayor inclusión de EC $(\mathrm{EC}-40, \mathrm{P}<0,05)$. Las diferencias entre los tratamientos pueden ser explicadas por el efecto de la extrusión del maíz. Ello permite una mayor disponibilidad de energía para las bacterias ruminales y una mejor sincronía entre energía y proteína.

Palabras clave: derivados de purinas, extrusión, alantoína, síntesis de proteína microbiana, Zea mays.

\section{LITERATURE CITED}

AFRC. 1992. Nutritive requirements of ruminant animal: Protein. Agricultural and Food Research Council (AFRC). Nutrition Abstracts and Reviews Series B 62:787-835.

ARC. 1984. The nutrient requirements of ruminant livestock Supplement $\mathrm{N}^{\circ}$ 1. Commonwealth Agricultural Bureaux. Agricultural Research Council (ARC), Slough, UK.

Allen, M. 1997. Relationship between fermentation acid production in the rumen and the requirement for physically effective fiber. Journal of Dairy Science 80:1447-1462.

Alvarado, Ch., R. Anrique, and S. Navarrete. 2009. Effect of including extruded, rolled or ground corn in dairy cow diets based on direct cut grass silage. Chilean Journal of Agriculture Research 69:356-365.

Anrique, R., R. Fuchslocher, S. Iraira, and R. Saldaña. 2008. Composición de alimentos para el ganado bovino. $3^{\text {a }}$ ed. Consorcio Lechero, Universidad Austral de Chile, Instituto de Investigaciones Agropecuarias INIA Remehue, Valdivia, Chile.

AOAC. 1996. Official methods of analysis. $15^{\text {th }}$ ed. Association of Official Analytical Chemists (AOAC), Washington, DC., USA.

Barchiesi, C., and R. Anrique. 2011. Ruminal degradability of dry matter and crude protein from moist dehulled lupin and rapeseed meal extruded. Chilean Journal of Agricultural Research 71:430436.

Beever, D., and B. Cottrill. 1994. Protein systems for feeding ruminant livestock: A European assessment. Journal of Dairy Science 77:2031-2043.

Chapoutot, P., and D. Sauvant. 1997. Nutritive value of raw and extruded pea-rapeseeds blends for ruminants. Animal Feed Science and Technology 65:59-77. 
Chen, X., Y. Chen, M. Franklin, E. Orskov, and W. Shand. 1992. The effect of feed intake and body weight on purine derivate excretion and microbial protein supply in sheep. Journal of Animal Science 70:1534-1542.

Chen, X., and M. Gomes. 1992. Estimation of microbial protein supply to sheep and cattle based on urinary excretion of purine derivatives- an overview of the technical details. International Feed Resources Unit. Rowett Research Institute, Occasional Publication, Bucksburn, Aberdeen, UK.

Chen, X., E. Orskov, and F. Hovell. 1990. Excretion of purine derivatives by ruminants: endogenous excretion, differences between cattle and sheep. British Journal of Nutrition 63:121-129.

Cros, P., C. Benchaar, C. Bayourthe, M. Vernay, and R. Moncoulon. 1991. In situ evaluation of the ruminal and intestinal degradability of extruded whole lupin seeds nitrogen. Reproduction Nutrition Development 31:575-583.

Dewhurst, R.J., D.R. Davies, and R.J. Merry. 2000. Microbial protein supply from the rumen. Animal Feed Science and Technology 85:1-21.

Firkins, J., A. Hristov, M. Hall, G. Varga, and N. St-Pierre. 2006. Integration of ruminal metabolism in dairy cattle. Journal of Dairy Science 89 (E. Suppl.): E31-E51.

Firkins, J., Z. Yu, and M. Morrison. 2007. Ruminal nitrogen metabolism: Perspectives for integration of microbiology and nutrition for dairy. Journal of Dairy Science 90 (E. Suppl.): E1E16.

Fujihara, T., T. Matsui, and T. Harumoto. 1991. Urinary excretion of purine derivatives and blood plasma level of allantoin in sheep and goats during fasting. p. 170-172. Proceedings of the $6^{\text {th }}$ International Symposium on Protein Metabolism and Nutrition, Herning, Denmark. 9-14 June. National Institute of Animal Science, Tjele, Denmark.

Fujihara, T., and M.N. Shem. 2011. Metabolism of microbial nitrogen in ruminants with special reference to nucleic acids. Animal Science Journal 82:198-208.

Givens, D., and H. Rulquin. 2004. Review: Utilisation by ruminants of nitrogen compounds in silage-based diets. Animal Feed Science and Technology 114:1-18.

Goering, H., and P. Van Soest. 1972. Forage fiber analyses (apparatus, reagents, procedures, and some applications). Agricultural Handbook $N^{\circ}$ 379. Agricultural Research Service (ARS), USDA, Washington DC, USA.

Gonzalez-Ronquillo, M., J. Balcells, J. Guada, and F. Vicente. 2003. Purine derivative excretion in dairy cows: endogenous excretion and the effect of exogenous nucleic acid supply. Journal of Dairy Science 86:1282-1291.

González-Ronquillo, M., J. Balcells, A. Belenguer, C. Castrillo, and M. Mota. 2004. A comparison of purine derivatives excretion with conventional methods as indices of microbial yield in dairy cows. Journal of Dairy Science 87:2211-2221.

Harrison, J.H., R. Blauwiekel, and M.R. Stokes. 1994. Fermentation and utilization of grass silage. Journal of Dairy Science 77:32093235

Karsli, M., and J. Russell. 2001. Effects of some dietary factors on ruminal microbial protein synthesis. Turkey Journal Veterinary Animal Science 25:681-686.

Martín-Orúe, S., J. Balcells, J. Guada, and M. Fondevila. 2000. Microbial nitrogen production in growing heifers: direct measurement of duodenal flow of purine bases versus urinary excretion of purine derivatives as estimation procedures. Animal Feed Science and Technology 88:171-188.
National Research Council. 2000. Nutrient requirements of beef cattle. $7^{\text {th }}$ Revised ed. National Academy Press, Washington, D.C. USA.

Offner, A., A. Bach, and D. Sauvant. 2003. Quantitative review of in situ starch degradation in the rumen. Animal Feed Science and Technology 106:81-93.

Orellana, P., N. Mendoza, and M. Scori. 1998. Relationship between urinary excretion of purine and creatinine derivatives. Archivos de Medicina Veterinaria 30:75-83.

Parker, R., and S.G. Ring. 2001. Aspects of the physical chemistry of starch. Journal of Cereal Science 34:1-17.

Rooney, L.W., and R.L. Pflugfelder. 1986. Factors affecting starch digestibility with special emphasis on sorghum and corn. Journal of Animal Science 63:1607-1623.

Russell, J. 1998. The importance of $\mathrm{pH}$ in the regulation of ruminal acetate to propionate ratio and methane production in vitro. Journal of Dairy Science 81:3222-3230.

SAS Institute. 2009. JMP 8 Design of experiments. SAS Institute, Cary, North Carolina, USA.

Schröder, A., K.H. Südekum, M. Brandt, and M. Gabel. 1997. Disappearance of amino acids from the gastrointestinal tract of dairy cows fed soybean meal or fish meal diets. Journal of Animal and Feed Sciences 6:53-69.

Shingfield, K. 2000. Estimation of microbial protein supply in ruminant animals based on renal and mamary purine metabolite excretion. A review. Journal of Animal and Feed Sciences 9:169212.

Solanas, E., C. Castrillo, J. Balcells, and J.A. Guada. 2005. In situ ruminal degradability and intestinal digestion of raw and extruded legume seeds and soya bean meal protein. Journal of Animal Physiology and Animal Nutrition 89:166-171.

Solanas, E., C. Castrillo, M. Fondevila, Q.O. Ruiz Narváez, and J.A. Guada. 2008. Effects of cereals and/or protein supplement extrusion on diet utilisation and performance of intensively reared cattle. Livestock Science 117:203-214.

Stern, M.D., G.A. Varga, J.H. Clark, J.L. Firkins, J.T. Huber, and D.L. Palmquist. 1994. Evaluation of chemical and physical properties of feeds that affect protein metabolism in the rumen. Journal of Dairy Science 77:2762-2786.

Südekum, K.-H., F. Brüsemeister, A. Schröder, and M. Stangassinger 2006. Effects of amount of intake and stage of forage maturity on urinary allantoin excretion and estimated microbial crude protein synthesis in the rumen of steers. Journal of Animal Physiology and Animal Nutrition 90:136-145.

Svihus, B., A. Uhlen, and O. Harstad. 2005. Effect of starch granule structure, associated components and processing on nutritive value of cereal starch: A review. Animal Feed Science and Technology 122:303-320

Tas, B.M., and A. Susenbeth. 2007. Urinary purine derivates excretion as an indicator of in vivo microbial $\mathrm{N}$ flow in cattle: A review. Livestock Science 111:181-192.

Van Soest, P., J. Robertson, and B. Lewis. 1991. Methods for dietary fiber, neutral detergent fiber and non starch polysaccharides in relation to animal nutrition. Journal of Dairy Science 74:35833597.

Verbic, J., X. Chen, N. MacLeod, and E. Orskov. 1990. Excretion of purine derivatives by ruminants: Effect of microbial nucleic acid infusion on purine derivative excretion by steers. Journal of Agricultural Science 114:243-248. 